\title{
ВАРІАЦІЙНА ПУЛЬСОМЕТРІЯ ЯК МЕТОД ВІДОБРАЖЕННЯ СИСТЕМНИХ ІНФОРМАЦІЙНИХ ЕНЕРГЕТИЧНИХ ПРОЦЕСІВ ТА ОЦІНКИ ФУНКЦІОНАЛЬНОГО СТАНУ ЛЮДСЬКОГО ОРГАНІЗМУ ПРИ ЗАГАЛЬНОМУ КЛІНІЧНОМУ ОБСТЕЖЕННІ ПАЦІЕНТІВ
}

ФГ. В. Невойт

\section{Українська медична стоматологічна академія, Полтава}

РЕзЮМЕ. Стаття присвячена клінічному значенню електромагнітних феноменів серцевої діяльності як джерелу додаткової клінічної інформації про функціональний стан хворого.

Мета - оцінити клініко-діагностичні можливості варіаційної пульсометрії як методу комп'ютеризованого аналізу короткого запису варіабельності ритму серця у відображенні системних інформаційних енергетичних процесів людського організму.

Матеріал і методи. Обстежено 247 респондентів у відкритому нерандомізованому контрольованому дослідженні із реєстрацією короткого запису варіабельності серцевого ритму з ортостатичною пробою і аналізом за методом варіаційної пульсометрії, проаналізовано результати у групах функціонально здорових респондентів різного рівня фізичної тренованості і хворих на неінфекційні захворювання.

Результати. Встановлено значний вегетативний дисбаланс у всіх хворих респондентів за показниками варіаційної пульсометрії, що відповідає наявній декомпенсації процесів адаптації. Встановлено вірогідні відмінності показників варіаційної пульсометрії і різну відповідь адаптаційної реакції на ортостаз у функціонально здорових респондентів різного ступеня тренованості.

Висновки. Варіаційна пульсометрія, як метод відображення системних інформаційних енергетичних процесів та оцінки функціонального стану людського організму, може бути рекомендована для застосування при здійсненні об'єктивного клінічного обстеження лікарями терапевтичного профілю. Дослідження вегетативного балансу регуляції серцевого ритму, аналізу варіаційної пульсометрії короткого запису варіабельності серцевого ритму може розглядатись як новий ранній предиктор ризику виявлення неінфекційних захворювань.

КЛючОВІ СлОВА: варіаційна пульсометрія; короткий запис варіабельності серцевого ритму; функціональний стан; неінфекційні захворювання.

"Серце знає про нас усе»

Л. Ю. Дорошенко, письменник, популяризатор методу короткого запису варіабельності серцевого ритму, 2020.

Присвячено світлій пам'яті автора методу варіабельності серцевого ритму Р. М. Баєвського (3.08.1928-31.05.2020).

Вступ. На сучасному етапі питання оптимізації ранньої діагностики і профілактики хронічних неінфекційних захворювань (НІ3) залишаються актуальними, оскільки НІЗ призводять щорічно до 41 млн випадків смертей, 15 млн яких серед осіб, які не досягли віку старості. Слід наголосити, що $70 \%$ летальних випадків $\epsilon$ наслідком патології серцево-судинної системи (ССС), тому подальше удосконалення діагностики та профілактики захворювань ССС залишається важливим [3, 4].

Рутинним, загальновизнаним і ефективним методом виявлення захворювань ССС $\epsilon$ електрокардіографія (ЕКГ), оскільки факт взаємозв'язку електричної активності кардіоміоцитів із їх функціональним і морфологічним станом доведений. Однак за даними аналізу ЕКГ неможливо діагностувати хворобу на стадії доклінічних проявів: електрокардіологічні симптоми у більшості випадків реєструються за умови наявності суттєвих функціональних і морфологічних змін у тканині серця та ССС. Поглиблення рівня фундаментальних знань про функціонування ССС, зокрема сучас- них уявлень про електромагнітні хвильові феномени серцевої діяльності і концепції, що серцевий ритм узагальнює ритми усіх фізіологічних процесів організму, може вдосконалити традиційно встановлені погляди на обсяг клінічної інформації, яку може отримати лікар при виконанні ЕКГ. На макрорівні саме серце $\epsilon$ органом, що задає ритм хвильовим коливальним процесам організму. Виділення зі складного коливання (яким і є скорочення серця) його вихідних простих коливань із подальшою клінічної оцінкою їх частоти та потужності дає лікареві можливість отримання об'єктивної індивідуальної детальної інформації про внесок механізмів регуляції у серцеву діяльність і про функціональний стан організму пацієнта загалом. Варіаційна пульсометрія (ВП) за Р. М. Баєвським є методом описової статистики ЕКГ для оцінки розподілу кардіоінтервалів із побудовою гістограми, розрахунком спеціальних індексів задля оцінки вегетативної регуляції серцевого ритму як критерію визначення параметрів функціонування ССС, що дає змогу верифікувати доклінічні стадії патології, здійснити контроль ефективності лікування HI3, прогноз, визначення об'єктивного рівня здоров'я пацієнта. Метод ВП був розроблений у 70-х роках XX сторіччя, однак залишався маловідомим серед лікарів практичної ланки охорони здоров'я і майже не використовувався в терапев- 
Огляди літератури, оригінальні дослідження, погляд на проблему, випадок з практики, короткі повідомлення

тичній практиці. Сучасний прогрес цифрових комп'ютерних технологій, поглиблення фундаментальних знань про функціонування ССС створили умови ренесансу для практичного застосування ВП і розуміння клініко-фізіологічної інтерпретації її результатів [1-3].

Мета - оцінити клініко-діагностичні можливості ВП як методу комп'ютеризованого аналізу короткого запису варіабельності ритму серця (BPC) у відображенні системних інформаційних енергетичних процесів людського організму задля підвищення в Україні ефективності заходів із запобігання та лікування НІЗ шляхом удосконалення їх діагностики та профілактики завдяки впровадження у медичну практику сучасних наукоємних технологій та розробки наукової концепції магнітоелектрохімічного обміну речовин.

Матеріал і методи дослідження. На базі навчально-практичного центру біофотоніки і валеології кафедри внутрішніх хвороб та медицини невідкладних станів Навчально-наукового інституту післядипломної освіти Української медичної стоматологічної академії (УМСА) та фізіотерапевтичного відділення комунального підприємства «О6ласна клінічна лікарня імені М. В. Скліфосовського Полтавської обласної ради» було виконано відкрите нерандомізоване контрольоване дослідження, фрагментом якого стало дослідження хвильових характеристик серцевого ритму у функціонально здорових респондентів із різними рівнями фізичної тренованості (основна група 1, n=171) і хворих на НІЗ із коморбідною патологією (контрольна група 2, n=76; медіана віку - $57(32 ; 83)$ років, чоловіки - 62 \%). Обстежені групи 1 були поділені на підгрупи 1А (функціонально здорові професійні спортсмени, футболісти футбольного клубу «Ворскла»; n=60, медіана віку - $19(15 ; 34)$ років, чоловіки - $100 \%$ ) та 1Б (функціонально здорові студенти, лікарі-інтерни, клінічні ординатори, УМСА, які не займаються систематично спортом; n=111 (медіана віку - 23 (19; 34) років, чоловіки - 78 \%). Для реєстрації короткого запису ВРС використовували програмно-апаратний комплекс Полі-спектр (Нейрософт, Росія) із автоматичним комп'ютеризованим виконанням обробки результатів, частиною аналізу якого була ВП. Реєстрацію короткого запису ВРС проводили згідно з програмним протоколом дослідження з дотриманням технічних вимог, комерційних рекомендацій щодо методики дослідження у фоновому режимі (5 хв) та активної ортостатичної проби (3 хв). Як прояв системних інформаційних енергетичних процесів оцінювали параметри ВП: моду (Мо, с; значення R-R, яке зустрічається найчастіше і вказує на домінуючий рівень функціонування синусового вузла), амплітуду моди (АМо, \%; кількість кардіоінтервалів, відпо- відних діапазону моди, що відображає міру мобілізувального впливу симпатичної нервової систеMи), індекс вегетативного рівноваги (IBP, ум. од.; $\mathrm{IBP}=\mathrm{AMo/BP),} \mathrm{що} \mathrm{вказує} \mathrm{на} \mathrm{співвідношення} \mathrm{між}$ активністю симпатичного і парасимпатичного відділів; вегетативний показник ритму (ВПР, ум. од.; $\mathrm{BПP}=1 / \mathrm{Mo} \times \mathrm{BP}$, де ВР - показник варіабельності серцевого ритму; характеризує парасимпатичні зрушення вегетативного балансу), індекс напруги регуляторних систем (IH, ум. од.; IH=AМо/(2ВР×Mо); відображає ступінь централізації управління серцевим ритмом), показник адекватності процесів регуляції (ПАПР, ум. од.); ПАПР=АМо/Мо; відображає відповідність між активністю симпатичного відділу вегетативної нервової системи та керуючим рівнем функціонування синусового вузла), стрес-індекс (Sl; дозволяє оцінити рівень функціонування синусового вузла (за рахунок гуморальних впливів) і співвідношення з активністю симпатичного відділу автономної нервової системи ступінь напруги і централізації управління серцевим ритмом); коефіцієнт 30:15 (К 30/15; відношення мінімального значення R-R-інтервалу, в районі 15 удару від початку вставання (RR15), до найдовшого R-R-інтервалу, близько 30 удару (RR30); характеризує реактивність парасимпатичного відділу вегетативної нервової системи поза залежністю від швидкості ортостазу і віку) [1-3].

Дослідження було схвалено етичною комісією УМСА, виконано з дотриманням усіх правил, етичних норм, на сертифікованому обладнанні. Статистичний аналіз проводили за допомогою програмного пакета Prism 5.0. Отримані дані представлені у вигляді середніх значень із їх середньою похибкою $(\mathrm{M} \pm \mathrm{m})$. Для оцінки достовірності відмінностей між групами оцінювали U-тест Манна - Уїтні. Відмінності вважали значущими при $\mathrm{p}<0,05$.

Результати й обговорення. Отримані при обстеженні респондентів результати варіаційної пульсометрії наведені у таблиці 1.

Практичне клінічне значення інтерпретації ВП полягає у визначенні вегетативного дисбалансу, як критерію, якій відображає наявний ступінь напруження адаптації і, відповідно, стадію доклінічних / клінічних змін (предикції появи захворювання). За даними літератури, адаптація перешкоджає збільшенню ентропії в процесі переходу організму від норми до патології. Загальний адаптаційний синдром забезпечує мобілізацію функціональних резервів організму. Відбуваються актуалізація і лабілізація функціональних систем, що веде до зниження ентропії. Перенапруження і виснаження регуляторних механізмів супроводжується збільшенням ентропії, що, зокрема, проявляється зменшенням узгодженості елементів функціональної системи, погіршенням їх синхронізації, ослабленням 
Огляди літератури, оригінальні дослідження, погляд на проблему, випадок з практики, короткі повідомлення Таблиця 1. Показники варіаційної пульсометрії за групами

\begin{tabular}{|c|c|c|c|}
\hline Показник & Група $1 \mathrm{~A}, \mathrm{n}=60$ & Група 15, n=111 & Група 2, n=76 \\
\hline \multicolumn{4}{|c|}{ Фоновий режим запису } \\
\hline AMo, \% & $23,51 \pm 6,88$ & $40 \pm 13,8^{1}$ & $57,65 \pm 16,46^{2,3}$ \\
\hline Mo, c & $0,81 \pm 0,30$ & $0,80 \pm 0,14$ & $0,91 \pm 0,2$ \\
\hline $\mathrm{SI}$ & $24,01 \pm 15,01$ & $117 \pm 139^{1}$ & $325,1 \pm 610,1^{2,3}$ \\
\hline ПАПР & $32,44 \pm 14,98$ & $48 \pm 23,3^{1}$ & $66,83 \pm 25,96^{2,3}$ \\
\hline ВПР & $2,14 \pm 1,18$ & $3,96 \pm 2,50^{1}$ & $9,06 \pm 22,06^{2,3}$ \\
\hline $\mathrm{IH}$ & $42,73 \pm 39,19$ & $91,7 \pm 99,1^{1}$ & $280,6 \pm 602,2^{2,3}$ \\
\hline IBP & $25,52 \pm 12,17$ & $146 \pm 128^{1}$ & $497,8 \pm 1170$ \\
\hline \multicolumn{4}{|c|}{ Ортостатична проба } \\
\hline AMo, \% & $38,79 \pm 11,62$ & $45,7 \pm 12,7^{1}$ & $60,45 \pm 16,8^{2,3}$ \\
\hline Mo & $1,06 \pm 0,12$ & $0,67 \pm 0,10^{1}$ & $0,78 \pm 0,18$ \\
\hline $\mathrm{SI}$ & $61,84 \pm 68,4$ & $196 \pm 181^{1}$ & $377 \pm 623^{2,3}$ \\
\hline IBP & $145,2 \pm 113,8$ & $195 \pm 153^{1}$ & $537,2 \pm 1198^{2,3}$ \\
\hline ПАПР & $55,99 \pm 21,28$ & $71,7 \pm 27,2^{1}$ & $82,82 \pm 33,81^{3}$ \\
\hline ВПР & $4,89 \pm 2,97$ & $6,24 \pm 3,51^{1}$ & $11 \pm 23,15^{2,3}$ \\
\hline $\mathrm{IH}$ & $106,6 \pm 94,72$ & $158 \pm 146^{1}$ & $354,3 \pm 648,4^{2,3}$ \\
\hline RR30, c & $0,93 \pm 0,18$ & $0,76 \pm 0,14$ & $0,82 \pm 0,18$ \\
\hline RR15, c & $0,62 \pm 0,09$ & $0,58 \pm 0,10$ & $0,72 \pm 0,17$ \\
\hline K 30/15 & $1,49 \pm 0,28$ & $1,33 \pm 0,23$ & $1,16 \pm 0,18$ \\
\hline
\end{tabular}

Примітка. ${ }^{1}$ - різниця достовірна при $p<0,0001$ між показниками $1 \mathrm{~A}, 1$ Б груп; ${ }^{2}$ - різниця достовірна при $p<0,0001$ між показниками 1Б, 2 груп; ${ }^{3}-$ різниця достовірна при $р<0,0001$ між показниками 1 A, 2 груп.

кореляційних зав'язків. Відповідно, за показниками ВП можна виділити чотири варіанти клінічної інтерпретації: 1) стан норми / задовільної адаптації; 2) стан підвищеного функціонального напруження механізмів адаптації із забезпеченням оптимальних адаптаційних можливостей за рахунок значного напруження регуляторних систем, підвищених витрат функціональних резервів організму; 3) стан перенапруження / незадовільної адаптації із зниженими функціональними можливостями організму з появою специфічних та неспецифічних змін з боку органів і систем; 4) стан виснаження регуляторних систем / зрив адаптації із розладами механізмів компенсації і зниженням функціональних можливостей організму. Р. М. БаєвСький запропонував розглядати зазначені стани як чотири варіанти здоров'я, де кожен із наступних має більший ризик виникнення хвороби, ніж попередній. Клінічні стадії захворювання характеризуються прогресуванням вегетативного дисбалансу, максимальним проявом якого $є$ так звана «вегетативна денервація» (відповідає аритміям тощо). Отримані нами дані клінічної інтерпретації ВП за групами підтвердили зазначену концепцію (табл. 1). Встановлено значний вегетативний дисбаланс у всіх респондентів групи 2 - значне зниження показників парасимпатичної (трофотропної) регуляції за одночасного збільшення показників, що характеризують активність симпатичного (ерготропного) відділу нервової системи, централізацію механізмів регуляції серцевого ритму: збільшення у фоновому режимі і після ортостатичної проби АМо при нормі 30-50 \%, IBP при нормі 35-145 ум. од., ПАПР при нормі 15-50 ум. од., ІН при нормі 80150 ум. од. Зазначене відповідає наявному у хворих НІЗ без значної декомпенсації процесів адаптації, оскільки у даному фрагменті дослідження було проаналізовано результати ВП респондентів із синусовим ритмом без клінічних ознак декомпенсації гемодинаміки. Порівняння показників фонового і ортостатичного режимів підтверджувало встановлений дисбаланс, оскільки мало місце достовірне збільшення після статичного навантаження $\mathrm{Mo}^{*}, \mathrm{SI}^{* *}, \mathrm{IH}^{* *}, \Pi \mathrm{A} \Pi \mathrm{P}^{* *}, \mathrm{~B} \mathrm{P}^{* *}$ ( ${ }^{*}-\mathrm{p}<0,001$; $\left.{ }^{* *}-\mathrm{p}<0,05\right)$. Встановлене свідчить про підсилення симпатикотонії / впливу синусового вузла на серцевий ритм, зростання централізації керування серцевим ритмом і, значить, що респонденти групи 2 / хворі на НІ3 мають значні прояви напруги адаптації із подальшою тенденцією до прогресування у напрямку «вегетативної денервації» серцевого ритму. Показники ВП у групі 1 у фоновому режимі відповідали нормі, однак характеризувались значущими відмінностями внаслідок різного ступеня тренованості у підгрупах. У підгрупі 1А показники ВП відповідали рівням норми як у фоновому так і в ортостатичному режимах, демонстрували домінанту парасимпатикотонічної регуляції, адекватну фізіологічну відповідь на стрес, що може відповідати першому варіанту здоров'я за Р. М. Баєвським. Показники респондентів підгрупи 1Б вірогідно відрізнялись від показників підгрупи 1А (табл. 1) і характеризу- 
Огляди літератури, оригінальні дослідження, погляд на проблему, випадок з практики, короткі повідомлення вались більшим внеском симпатичної нервової системи, вірогідно більшим рівнем індексів напруги, які після виконання ортостатичного тесту вийшли за межі норми. Це свідчить про потребу в більшій мобілізації ресурсів - більшу «ціну адаптації» у респондентів підгрупи 1Б, порівняно із тренованими респондентами підгрупи 1А. Зазначене дозволяє віднести респондентів 1Б вже до другого варіанта здоров'я за Р. М. Баєвським. Зроблені висновки за групами підтверджувались К 30/15, який, за даними літератури, характеризує реакцію адаптації на ортостаз. Відповідно до клінічно можливих варіантів реакції: нормальна (К 30/15=1,25-1,75), знижена ( $\mathrm{K} \mathrm{30/15=1-1,25),} \mathrm{парадоксальна} \mathrm{(К} \mathrm{30/15<1),}$ надлишкова (К 30/15>1,75), - у основній групі реєструвалась адекватна реакція підтримання гомеостазу на відповідному рівні при ортостазі, в групі контролю - знижена, що відповідало пригніченню функціонального стану організму при НІ3 [1-3].

Висновки. ВП $є$ методом відображення системних інформаційних енергетичних процесів та оцінки функціонального стану людського організму, який дозволяє із запису ЕКГ отримувати інтегральну о6'єктивну інформацію про функціональний стан організму.

\section{ЛІТЕРАТУРА}

1. Баевский Р. М. Прогнозирование состояния на грани норм и патологии / Р. М. Баевский. - М. : Книга по требованию, 2014. - 295 с.

2. Михайлов В. М. Вариабельность ритма сердца (новый взгляд на старую парадигму) / В. М. Михайлов. Иваново : ООО «Нейрософт», 2017. - 516 с.

3. The study of the electromagnetic component of the human body as a diagnostic indicator in the examina-

\section{REFERENCES}

1. Baevsky, R.M. (2014). Prognozirovanie sostoyaniy na grani normy i patologii [Prediction of conditions on the verge of norm and pathology. Book on demand]. Moscow: Kniga po Trebovaniyu [in Russian]

2. Mihaylov, V.M. (2017). Variabelnost ritma serdtsa (novyy vzglyad na staruyu paradigmu) [Heart rate variability (a new look at the old paradigm)]. Ivanovo: OOO "Neyrosoft" [in Russian]

3. Mintser, O.P., Semenets, V.V., Potiazhenko, M.M., Podpruzhnykov, P.M., \& Nevoit, G.V. (2020). The study of

Враховуючи простоту, швидкість виконання, доступність, метод ВП може бути рекомендований для застосування при здійсненні об'єктивного клінічного обстеження лікарями терапевтичного профілю задля раннього скринінгу захворювань ССС, здійснення первинної профілактики, контролю ефективності лікування.

Дослідження вегетативного балансу регуляції серцевого ритму ВП аналізу короткого запису ВСР може розглядатись у якості нового раннього предиктора ризику виявлення НІ3.

Перспективи подальших досліджень полягають у розробці чітких клінічних рекомендацій, які будуть сприяти широкому впровадженню методу короткого запису ВСР як інструменту отримання об'єктивної клінічної інформації безпосередньо при здійсненні клінічного обстеження хворих терапевтичного профілю. Принципове значення має подальше фундаментальне вивчення ролі електромагнітних феноменів організму людини як проявів системних інформаційних енергетичних процесів та можливості їх практичного використання в клінічній медицині.

Конфлікт інтересів відсутній.

tion of patients with Non-communicablediseases: problem statement / O. P. Mintser, V. V. Semenets, M. M. Potiazhenko [et al.] // Wiadomości Lekarskie. - 2020. - Vol. 6 (73). P. 1279-1283.

4. WHO, 2018. Noncommunicable diseases. [Internet]. - Access mode : http://www.who.int/news-room/ fact-sheets/detail/noncommunicable-diseases

the electromagnetic component of the human body as a diagnostic indicator in the examination of patients with Non-communicablediseases: problem statement. Wiadomości Lekarskie, 6 (73), 1279-1283.

4. WHO. (2018). Non-Communicable diseases. [Internet]. Retrieved from: http://www.who.int/news-room/ fact-sheets/detail/noncommunicable-diseases. 


\title{
Огляди літератури, оригінальні дослідження, погляд на проблему, випадок з практики, короткі повідомлення \\ ВАРИАЦИОННАЯ ПУЛЬСОМЕТРИЯ КАК МЕТОД ОТОБРАЖЕНИЯ СИСТЕМНЫХ ИНФОРМАЦИОННЫХ ЭНЕРГЕТИЧЕСКИХ ПРОЦЕССОВ И ОЦЕНКИ ФУНКЦИОНАЛЬНОГО СОСТОЯНИЯ ЧЕЛОВЕЧЕСКОГО ОРГАНИЗМА ПРИ ОБЩЕМ КЛИНИЧЕСКОМ ОБСЛЕДОВАНИИ ПАЦИЕНТА
}

\author{
Украинская медицинская стоматологическая академия, Полтава
}

๑А. В. Невойт

РЕзЮМЕ. Статья посвящена клиническому значению электромагнитных феноменов сердечной деятельности как источнику дополнительной клинической информации о функциональном состоянии пациента.

Цель - оценить клинико-диагностические возможности вариационной пульсометрии как метода компьютеризованного анализа короткой записи вариабельности ритма сердца в отображении системных информационных энергетических процессов человеческого организма.

Материал и методы. Обследованы 247 респондентов в открытом нерандомизированном контролируемом исследовании с регистрацией короткой записи вариабельности сердечного ритма с ортостатической пробой и анализом методом вариационной пульсометрии, проанализированы результаты в группах функционально здоровых респондентов разных уровней физической тренированности и больных неинфекционными заболеваниями.

Результаты. Установлен значительный вегетативный дисбаланс у всех больных респондентов по показателям вариационной пульсометрии, что соответствует имеющейся декомпенсации процессов адаптации. Установлены достоверные различия показателей вариационной пульсометрии и разный ответ адаптационной реакции на ортостаз у функционально здоровых респондентов различной степени тренированности.

Выводы. Вариационная пульсометрия, как метод отображения системных информационных энергетических процессов и оценки функционального состояния человеческого организма, может быть рекомендована для применения при осуществлении объективного клинического обследования врачами терапевтического профиля. Исследование вегетативного баланса регуляции сердечного ритма путем анализа вариационной пульсометрии короткой записи вариабельности сердечного ритма может рассматриваться в качестве нового раннего предиктора риска выявления неинфекционных заболеваний.

КЛЮЧЕВЫЕ СЛОВА: вариационная пульсометрия; короткая запись вариабельности сердечного ритма; функциональное состояние; неинфекционные заболевания.

\section{VARIATION PULSOMETRY AS A METHOD FOR DISPLAYING SYSTEMIC INFORMATION ENERGY PROCESSES AND ASSESSING THE FUNCTIONAL STATE OF THE HUMAN BODY DURING AN OBJECTIVE STRUCTURED CLINICAL EXAMINATION}

๑G. V. Nevoit

\author{
Ukrainian Medical Stomatological Academy, Poltava
}

SUMMARY. The article is devoted to the clinical significance of the electromagnetic phenomena of cardiac activity as a source of additional clinical information about the functional state of the patient.

The aim - to evaluate the clinical and diagnostic capabilities of variational pulsometry as a method of computerized analysis of a short recording of heart rate variability in the display of systemic informational energy processes of the human body.

Material and Methods. 247 respondents were examined in an open, non-randomized, controlled study with the registration of a short recording of heart rate variability with an orthostatic test and analysis by the method of variational pulsometry. The results were analyzed in groups of functionally healthy respondents of different levels of physical fitness and patients with non-communicable diseases.

Results and Discussion. Significant autonomic imbalance was found in all sick respondents in terms of variational pulsometry. This corresponded to the decompensation of adaptation processes that the patients had. Significant differences in the indicators of variational pulsometry and different responses of the adaptive response to orthostasis in functionally healthy respondents of varying degrees of fitness were established.

Conclusions. Variation pulsometry can be recommended for use in the implementation of an objective clinical examination by physicians of a therapeutic profile as a method of displaying systemic information energy processes and assessing the functional state of the human body. The study of the autonomic balance of the regulation of the heart rate by the analysis of the Variation pulsometry of a short recording of the heart rate variability can be considered as a new early predictor of the risk of detecting non-communicable diseases.

KEY WORDS: variation pulsometry; short recording of heart rate variability; functional state; non-communicable diseases.

Отримано 12.10.2020 